\title{
Scolex Morphology of Proteocephalid Cestodes Parasites of Neotropical Freshwater Fishes
}

\section{Amilcar Arandas Rego}

Departamento de Helmintologia, Instituto Oswaldo Cruz, Av. Brasil 4365, 21045-900 Rio de Janeiro, RJ, Brasil

The morphology of the scolices and metascolices of 29 proteocephalid species, parasites of freshwater fishes from Brazil was compared by using scanning electron microscope, light and laser microscopy. The following species were evaluated: Proteocephalus vazzolerae, P. piramutab, Robertiella paranaensis, Travassiella avitellina, Monticellia loyolai, M. spinulifera, M. belavistensis, Houssayela sudobim, Zygobothrium megacephalum, Gibsoniela mandube, Cangatiella arandasi, Nomimoscolex sudobim, N. lopesi， N. admonticellia, N. piraeeba, N. pirarara, Harriscolex kaparari, Crepidobothrium eirasi, Spatulifer rugosa, Megathylacus brooksi, Choanoscolex abscisus, Amphoteromorphus peniculus, A. piraeeba, Paramonticellia itaipuensis, Peltidocotyle rugosa, Othinoscolex lenha, Rudolphiella rugata, R. piranabu, Jauella glandicephalus.

Some features as overall shape of scolex, suckers, apical sucker, frontal glands and several kinds of metascolex were analyzed. The taxonomic importance of scolex and metascolex is discussed.

Key words : Cestoda Proteocephalidea - parasites of freshwater fishes - South American fish parasites

Proteocephalid Cestodes are parasites of freshwater fishes, specially Siluriforms (catfishes), Amphibia and Reptilia. They are the most importante parasites in Siluriforms, considering the number of parasite species described within those hosts.

The morphology of the scolex is one of the most important characteristics used for classification of proteocephalids at generic and subamily level (Scholz et al. 1998). However, morphological features of scolex/metascolex have been neglected in the definition of the subfamilies and families, particularly in the classification of South American proteocephalids. Woodland (1933-1935) and the following authors preferred to utilise the characteristics of reproductive organs, and their relationships with the internal longitudinal musculature to separate the taxa. Rego (1995) disagreed with this scheme of classification, and proposed the elimination of the Monticelliidae and its subfamilies, based in the fact that the actual classification is not suitable for the forms of proteocephalids recently described, which present intermediate characteristics, and others with inconspicuous longitudinal musculature, resulting the impossibility of the definition of the taxa they belong to.

Research fellow of CNPq (Cat. I-A). Fax: $+55-21-$ 264.8974. E-mail: arego@gene.dbbm.fiocruz.br and arego@openlink.com.br

Received 3 June 1998

Accepted 13 October 1998
Rego et al. (1998) carried a cladistic analysis based on comparative morphology, to examine the subfamily-level relationships within the order Proteocephalidea. The study did not evaluate relationships at the generic level, particularly those within the Monticelliidae (sensu Rego 1994). It is fundamental to conduct a phylogenetic analyses of the genera, to the resolution of taxonomic problems of South American proteocephalids. In that paper, on considering the character metascolex, only two states were considered (presence versus absence). However, several types of metascolex have been recognized by the authors. The goal of the present paper is to contributes to a definition and to distinguish the several types of these structures.

To find suitable characters on the division of taxa genera, a comparative study of the scolex/ metascolex of proteocephalid species from South American proteocephalid fishes was carried out and the results are presented herein.

\section{MATERIALS AND METHODS}

The majority of the specimens studied in this work was collected in recent years from the Amazon Siluriform fishes and from Paraná and Cuiaba rivers.

Specimens for scanning electron microscopy (SEM) were dehydrated, critical point dried, covered with gold and observed under a Phillips 501B; the voltage used was 7.2 , or $15 \mathrm{kv}$. Some species were photographed in Zeiss Confocal LSM 410 and in a Zeiss Axyophoto. 


\section{RESULTS}

Scolex - The scolex is generally dorso-ventrally flattened. The scolex can be rounded, quadrangular (Fig. 2). The big scolices are wider than the proglottids (Fig. 33 ) or smaller (Fig. 29).

Spines (microtriches ?) can be found covering the suckers, described from Monticellia spinulifera Woodland, 1935 (Figs 3, 27), Nomimoscolex piraeeba Woodland, 1934 (Fig. 23) and in a few more species. Rarely, spines can be observed on the entire scolex and the strobila. This character was described from two Argentinian species, Nomimoscolex microacetabula Pertierra, 1995 and N. alovarius Pertierra, 1995 (Rego et al. in press).

Suckers - The suckers can be directed anteriorly (Figs 17, 31), laterally (Figs 1, 6), or anterolaterally (Fig. 4). The diameter of sucker is varied; they can be small in relation to scolex (Fig. 5) or relatively bigger (Fig. 6). They are small when the relation between the diameter of sucker with the scolex wider, represents less than $30 \%$. The suckers are generally round or oval, except in rare uniloculate suckers' species (Fig. 26), the biloculate and the triloculate suckers are elongated (Fig. 11).

Sucker cavities - They could be simple or uniloculate, as in Proteocephalus and Nomimoscolex (Figs 5, 6). With one cavity, but notched, heart-shaped as in Crepidobothrium eirasi (Fig. 7); or with one cavity, but with two appertures, as in Zygobothrium megacephalum (Figs 8, 32, 33); biloculate, with two apertures separated by a partition, in the species Robertiella paranaensis (Fig. 4), Peltidocotyle rugosa (Fig. 9), Goezeella siluri, Othinoscolex lenha (Fig.10) and Amphoteromorphus peniculus, or finally, triloculate, as in Gibsoniela mandube (Figs 2, 11, 12).

Sucker' projections - Unguiculate projections from the suckers can be found in Harriscolex kaparari (Fig.13); auriculate form in the species Houssayela sudobim (Fig. 15) or of papillae-like, in Nomimoscolex alovarius Brooks \& Deardorff, 1980.

Domus - Domus of cornified tissue can be observed in the scolex of $H$. kaparari (Fig. 14).

Suckers' sphincter - Beyond the inherent suckers muscles, it can be found muscles of sphincterian type in the opening of the suckers; they are strong, completely developed in Megathylacus species (Fig. 16) or incompletely developed, in Mariauxiella pimelodi Chambrier \& Rego, 1995.

Internal suckers - Most of the proteocephalid species have salient suckers, projected from the scolex (Figs 6, 24), but in Megathylacus brooksi Pavanelli \& Rego, 1985 and in Paramonticellia itaipuensis Pavanelli \& Rego, 1991, in sections, the suckers seems as internal sacs, appearing as holes in the surface of scolex (Figs 17, 18).

Apical sucker - Also designed fifth sucker; they are frequently found in species of Proteocephalus and Ophiotaenia; sometimes they could be very conspicuous (Fig. 19), but in some species they are difficult to observe, even by SEM observation.

Suckers bothridia-like - Very few species of proteocephalids have sukers of non-acetabulate type; that is the case of Proteocephalus piramutab (Woodlamd, 1933); this species was originally described in the genera Anthobothrium, a tetraphyllidean; the suckers are phyllidia-like as described by Woodland (Fig. 25). Other exemple is Gibsoniela mandube, which has suckers triloculate, they remind the ones of Tetraphyllidea (Figs $2,11,12$ ).

Apical glands - Also known as frontal glands. There are different hystological types of these structures; they are more frequent in species of Proteocephalus, Ophiotaenia and Nomimoscolex, genera without metascolex, but described from one species with metascolex (Jaulla glandicephalus). These glands can be easily observed in stained preparations of scolex or in sections (Fig. 20); by SEM photographs it is possible to observe the apperture of these glands in the apical region of scolex (Fig. 21).

In this work it is analysed the scolex of the following species: Monticellia belavistensis Pavanelli, Santos \& Takemoto, 1994, Monticellia spinulifera Woodland, 1935, Monticellia loyolai Pavanelli \& Santos, 1992, Proteocephalus vazzolerae Pavanelli \& Takemoto, 1995, Proteocephalus piramutab (Woodland, 1933), Harriscolex kaparari (Woodland,1935), Nomimoscolex admonticellia (Woodland, 1934), Houssayella sudobim (Woodland,1935), Nomimoscolex lopesi Rego, 1989, Nomimoscolex piraeeba Woodland, 1934, Nomimoscolex sudobim Woodland,1935, Nomimoscolex pirarara (Woodland, 1935), Travassiella avitellina Rego \& Pavanelli, 1987, Cangatiella arandasi Pavanelli \& Santos, 1991, Gibsoniela mandube (Woodland, 1935), Zygobothrium megacephalum Diesing, 1850, Robertiella agostinhoi (Pavanelli \& Santos, 1992), Robertiella paranaensis (Pavanelli \& Rego, 1989 and Crepidobothrium eirasi Rego \& Chambrier, 1995).

- Monticellia loyolai. Scolex round with an apex; no wrinkles or furrows present; suckers directed laterally; neck with some wrinkles (Fig. 1).

- Gibsoniela mandube. Scolex quadrangular; there is an apex; suckers bothridia-like, with tree loculi; suckers antero-laterally; neck present (Figs 2, 11, 12).

- Robertiella paranaensis. Scolex with suckers biloculate; there are some wrinkles on the scolex; 
suckers directed antero-laterally; neck present (Figs 4, 30).

- Monticellia belavistensis. Escolex quadrilobed from above; suckers disposed antero-laterally; no apex present on scolex (Fig. 5).

- Monticellia spinulifera [Syn.: Spasskyelina spinulifera (Woodland, 1935) Freze, 1965]. Scolex small, suckers with spines on borders (Fig. 27).

- Nomimoscolex lopesi. Scolex with big suckers, laterally disposed; no apex present; neck conspicuous; some longitudinal wrinkles on neck (Fig. 6).
- Harriscolex kaparari. Scolex with a cornified domus; suckers with unguiculate protrusions; no wrinkles on scolex (Figs 13, 14).

- Houssayella sudobim. Scolex with an irregular apex ; horny projections from the suckers. No neck (Fig. 15).

- Proteocephalus vazzolerae. Scolex not delimited from neck; suckers round; apical sucker conspicuous; no wrinkles on scolex; neck long (Fig. 19).

- Nomimoscolex piraeeba. Scolex rounded, with an apical glandular organ, "os terminale", open-
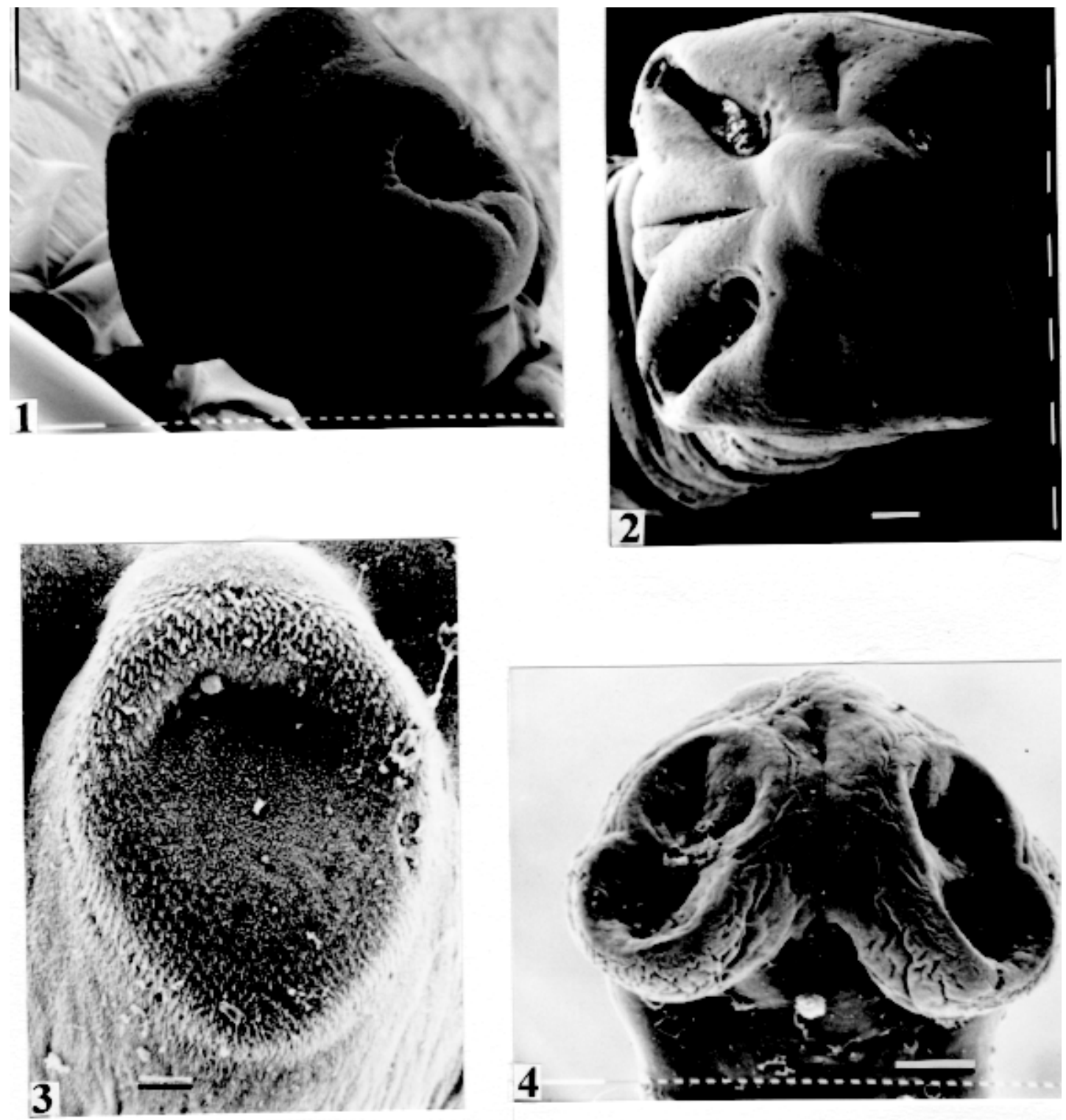

Fig. 1: Monticellia loyolai. SEM. Scolex (original). Bar $=0.100 \mathrm{~mm}$. Fig. 2: Gibsoniela mandube. SEM. Scolex apical view. Triloculate suckers. Original. Bar $=0.100 \mathrm{~mm}$. Fig. 3: Monticellia spinulifera. SEM. Detail of spines in the opening of sucker. Original. Bar $=0.020 \mathrm{~mm}$. Fig. 4: Robertiella paranaensis. SEM. Biloculate suckers. Original. Bar $=0.050 \mathrm{~mm}$. 
ing on its apex; minute spines on borders of suckers and some parts of scolex (Figs 20, 21, 22, 23). - Nomimoscolex admonticellia. Scolex with apical glandular region; suckers oriented laterally, sa-

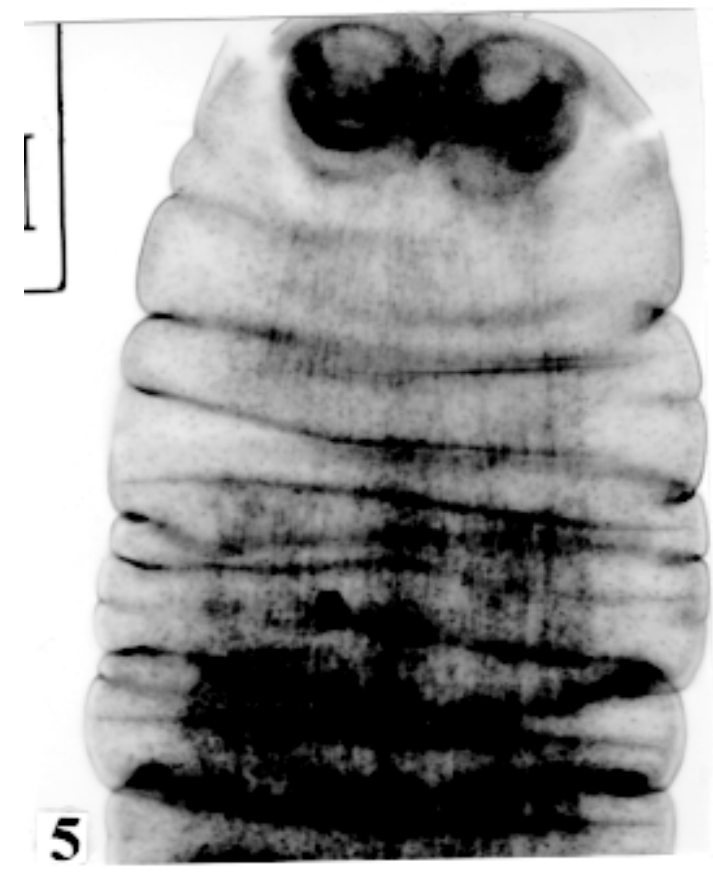

lient, located in funnel-shaped portions of scolex; neck present (Fig. 24).

- Proteocephalus piramutab. Scolex consists of a central pillar, bearing four suckers phyllidia-like;
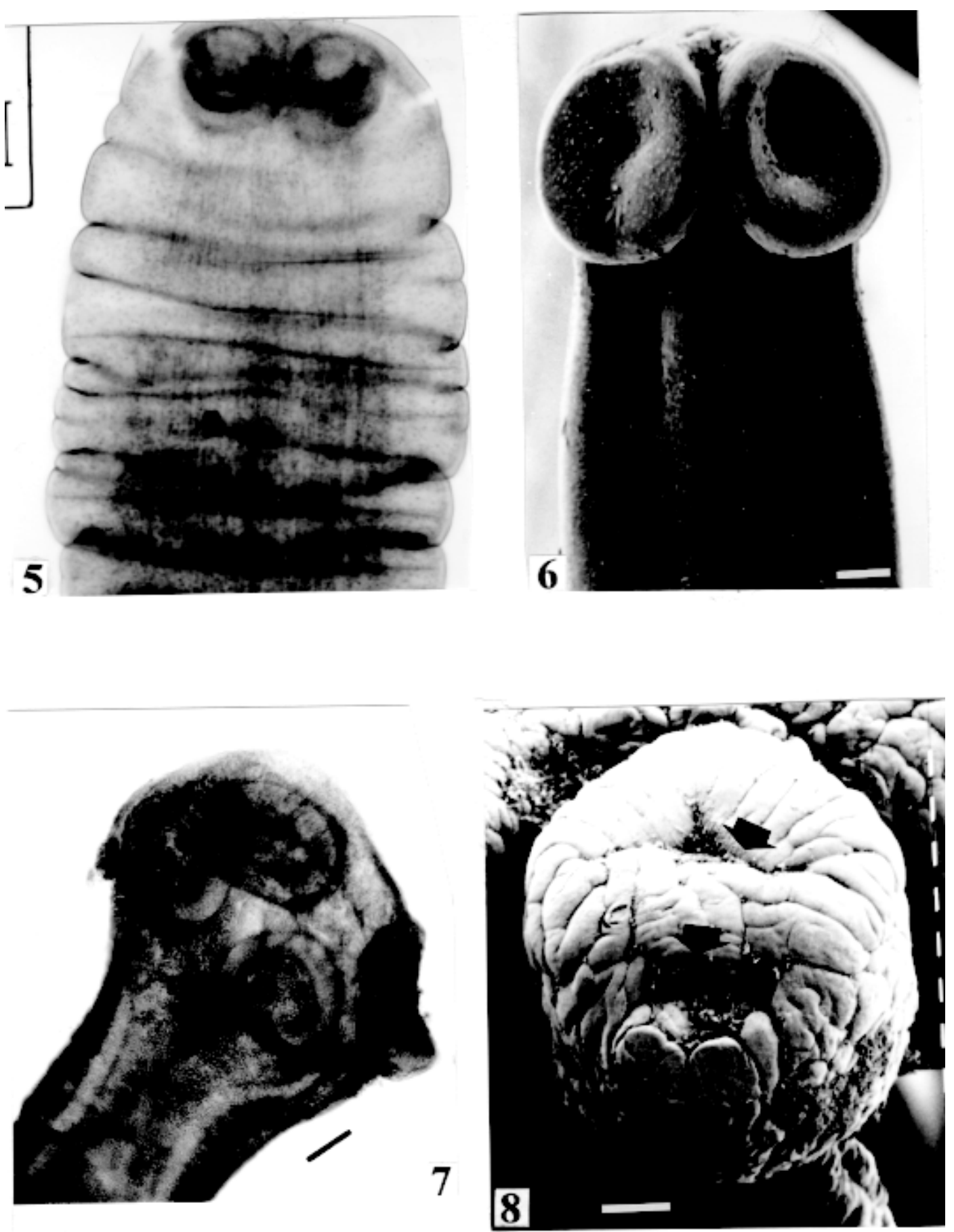

Fig. 5: Monticellia belavistensis; scolex contracted. Confocal microscope. Original. Bar $=0.100 \mathrm{~mm}$. Fig. 6: Nomimoscolex lopesi. SEM. Note the big suckers. Original. Bar $=0.100 \mathrm{~mm}$. Fig. 7: Crepidobothrium eirasi. SEM. Suckers notched. original. Bar $=0.100 \mathrm{~mm}$. Fig. 8: Zygobothrium megacephalum. SEM. One sucker, two appertures (arrows). Original. Bar $=0.200 \mathrm{~mm}$. 
they have the form of thick-walled cups. There is a small apex (Fig. 25).

- Nomimoscolex sudobim. Scolex with elongated suckers, with weak musculature. Neck wrinkled (Fig. 26).

- Nomimoscolex pirarara. Scolex wider than strobila; pleomorphic; some wrinkles on apex of scolex; suckers oriented anteriorly (Fig. 31).

- Travassiella avitellina. Scolex small; suckers salient (Fig. 28). Neck elongated.
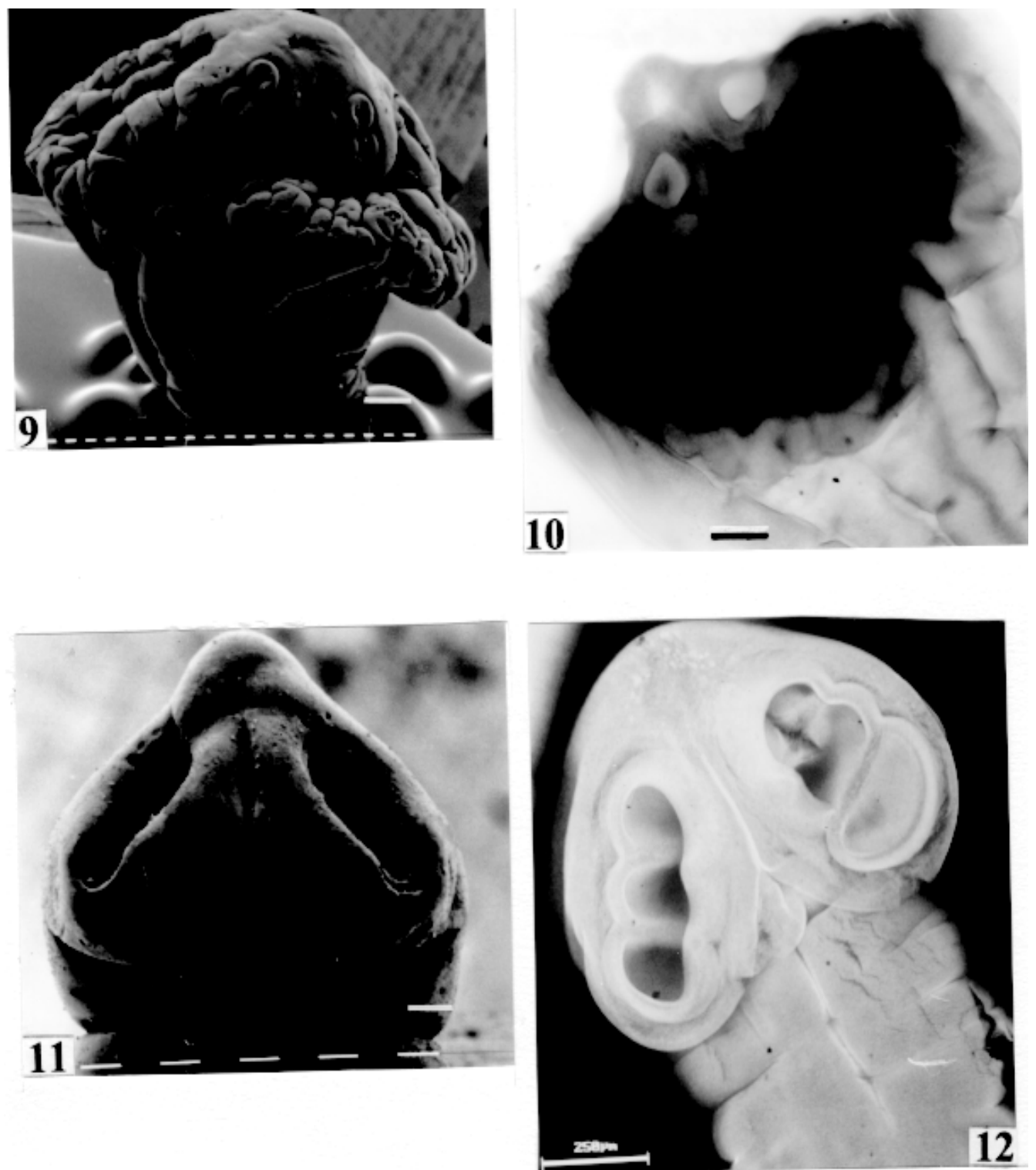

Fig. 9: Peltidocotyle rugosa. SEM. Biloculate suckers (arrows). Original. Bar $=0.250 \mathrm{~mm}$. Fig. 10: Othinoscolex lenha . Confocal microscope. Biloculate suckers on apical part of scolex. Original. Bar $=0.100 \mathrm{~mm}$. Fig. 11: Gibsoniela mandube. SEM. Lateral view of scolex. Suckers triloculate. Original. Bar $=0.100 \mathrm{~mm}$. Fig. 12: G. mandube. Confocal microscope. Triloculate suckers. Original. $\mathrm{Bar}=0.250 \mathrm{~mm}$. 
Metascolex - Freze (1965) defined metascolex as ".. a small number of large folds, situated behind the suckers. The cuticular and subcuticular layers and the cortical parenchyme tissue participate in the formation of folds". I prefer defining metascolex as, "any development of folds and wrinkles in the posterior part of scolex or in the surface of scolex properly, encircling the sucker or not".
It is interesting to note that a sort of "collar" can also be observed in genera of the orders Caryophyllidea, Tetraphyllidea, Lecanicephalidea and Tetrabothriidea. Nothwithstanding, the forms of metascolex found in proteocephalids are quite different from the ones found in the other orders of Eucestoda.

There are several types of metascolex, as many as the number of described species with metascolex.
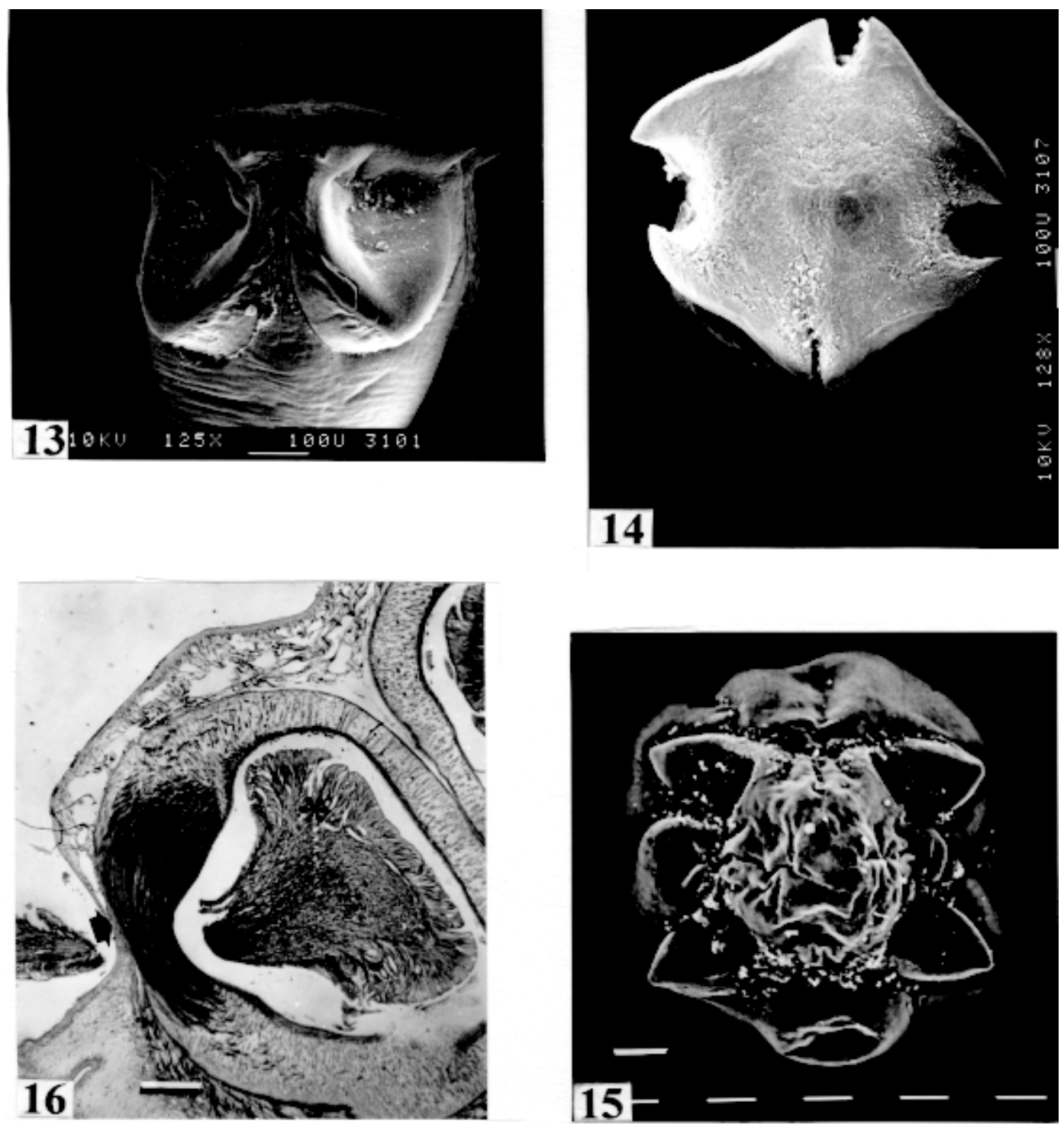

Fig. 13: Harriscolex kaparari. SEM. Suckers with projections and a cornified domus (arrows). Original. Bar $=0.100 \mathrm{~mm}$. Fig. 14 : H. kaparari. SEM. Apical view of scolex' domus. Original. Bar $=0.100 \mathrm{~mm}$. Fig. 15: Houssayela sudobim. SEM. Scolex, apical view. Note the apex of scolex and horny projections of suckers. Original. Bar $=0.050 \mathrm{~mm}$. Fig. 16: Megathylacus brooksi. Light microscope. Section of scolex; note a sucker's sphincter (arrow). Original. Bar $=0.100 \mathrm{~mm}$. 
There is not a morphological evolutive sequence linking the types, an evidence that this character followed separates, convergent evolutions.

There are metascolex very conspicuous, "collar-like", found in the species of the genera Goezeella, Peltidocotyle, Spatulifer, Rudolphiella and Amphoteromorphus. In these species the suckers are enveloped by folds of metascolex, and sometimes also by digitiform processes; the suckers are seen
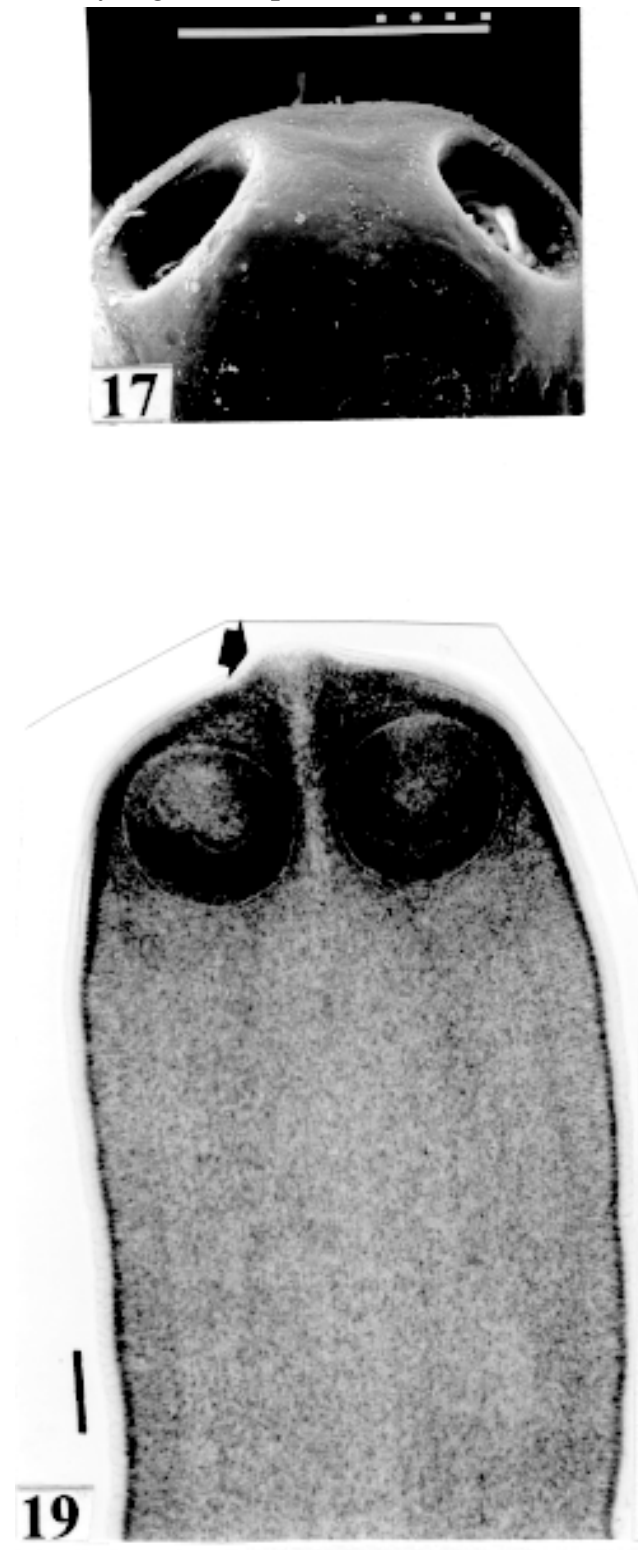

when the scolex is somewhat expanded (Fig. 34). We found metascolex less developed in the species Choanoscolex abscisus; the folds of metascolex covers only partially the base of suckers (Fig. 36); and metascolex in which lacks true folds, Paramonticellia itaipuensis, their delicate folds are better observed in SEM (Fig. 18). The species with developed metascolex commonly have wrinkles and furrows along the entire strobila.
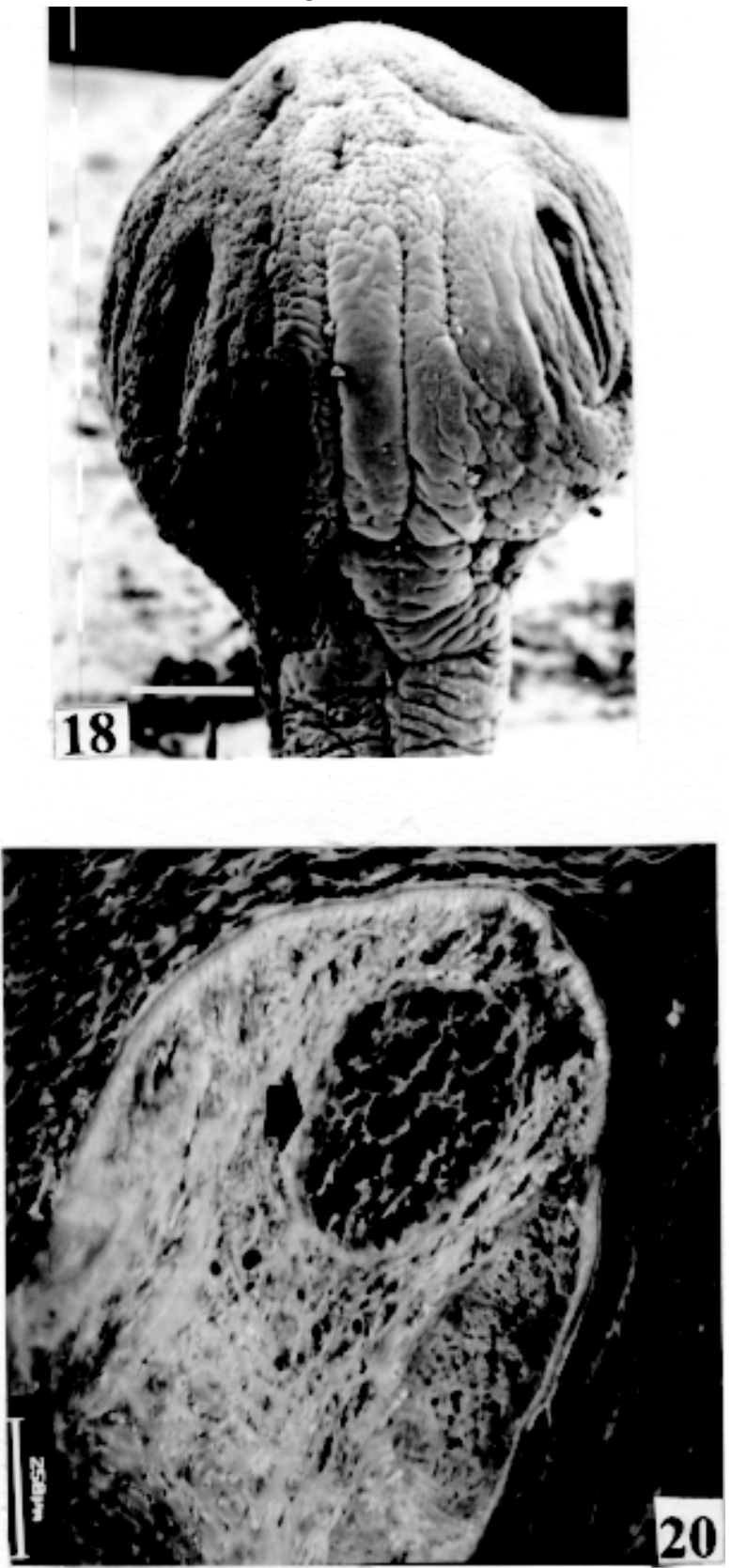

Fig. 17: Megathylacus brooksi. SEM. Holes of the suckers. Original. Bar $=1 \mathrm{~mm}$. Fig.18: Paramonticellia itaipuensis. SEM. Wrinkles and delicate folds on entire surface of scolex and suckers. Original. Bar $=0.200 \mathrm{~mm}$. Fig. 19: Proteocephalus vazzolerae. Confocal microcope. Apical sucker (arrow). Original. Bar $=0.100 \mathrm{~mm}$. Fig. 20: Nomimoscolex piraeeba. Confocal microscope; reflected light. Section of scolex with the apical gland (arrow). Original. Bar $=0.250 \mathrm{~mm}$. 
Chambrier and Paulino (1997) described Proteocephalus joanae from a South American snake; they denominated metascolex a swollen elongated posterior part of its scolex, but, in my opinion, the structure they described can hardly be considered a metascolex; however such structure in very unusual in the genus Proteocephalus.
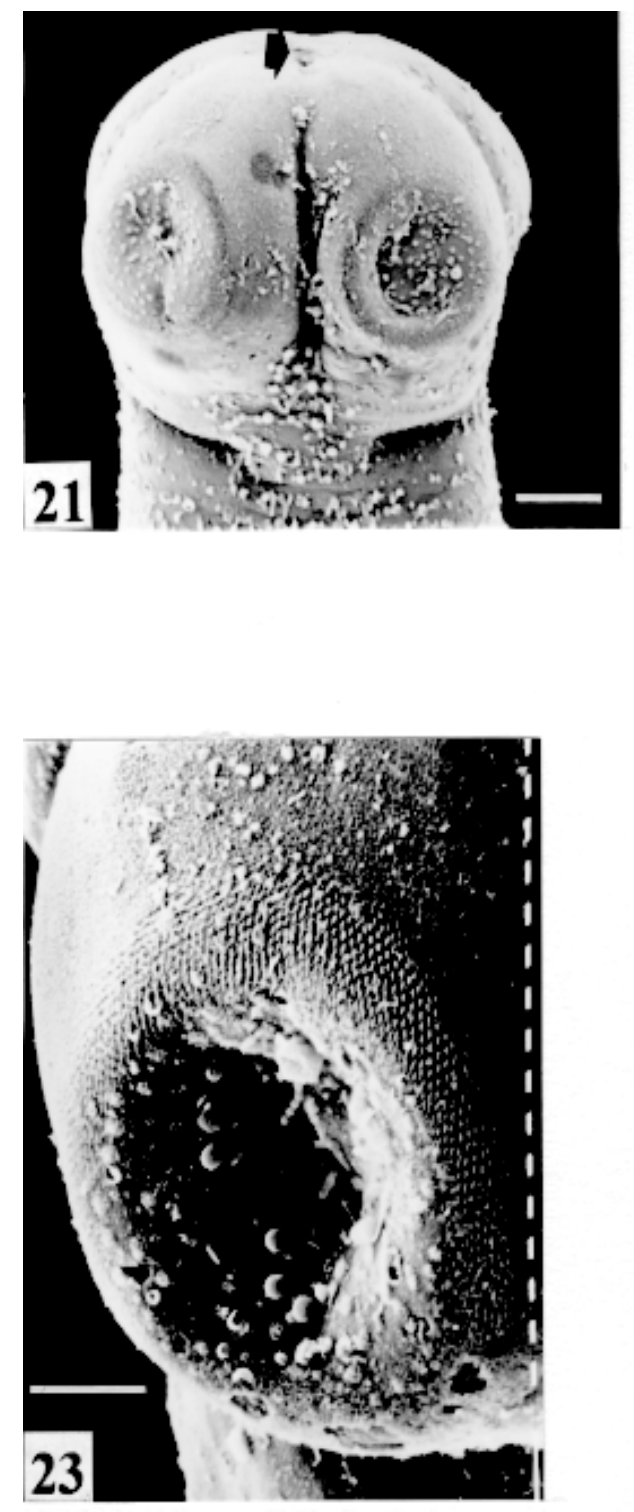

It is analyzed the metascolex of the following species : Spatulifer rugosa (Woodland,1935), Megathylacus brooksi Rego \& Pavanelli, 1985, Amphoteromorphus peniculus Diesing, 1850, Amphoteromorphus piraeeba Woodland, 1934, Peltidocotyle rugosa Diesing, 1850, Othinoscolex lenha Woodland, 1933, Rudolphiella rugata (Rego,
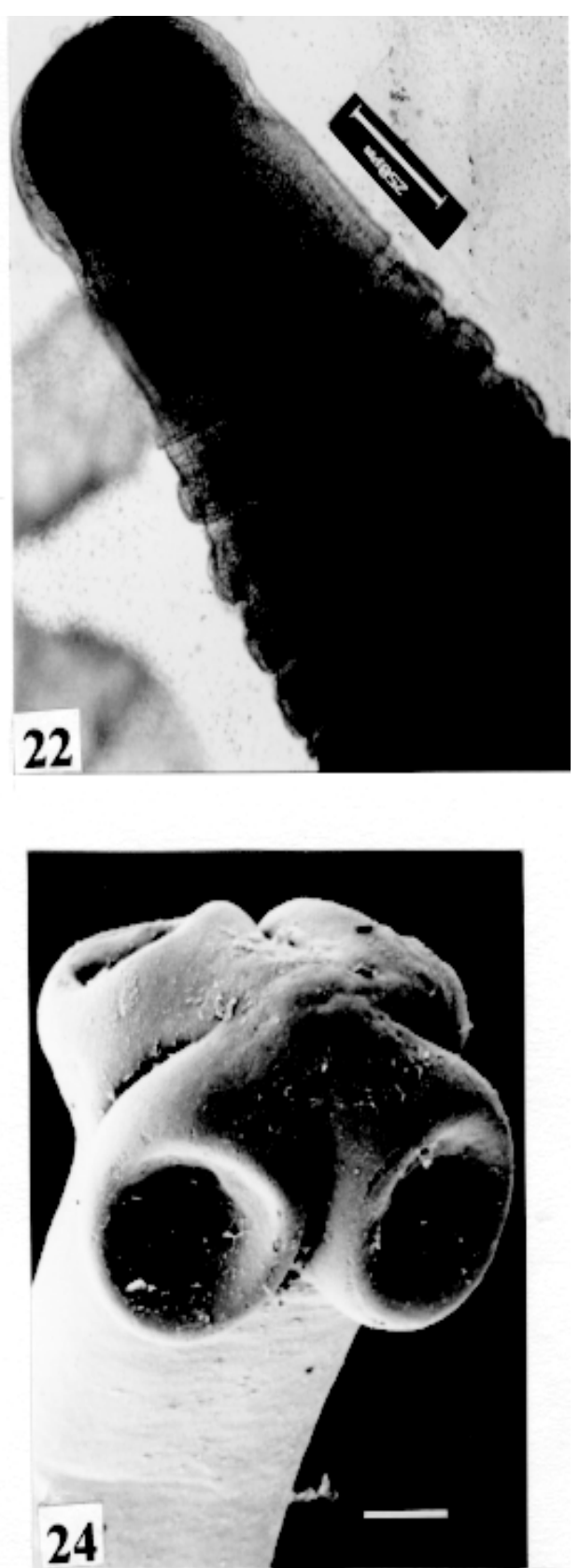

Fig. 21: Nomimoscolex piraeeba. SEM. Opening of apical gland (arrow). Scale bar $=0.100 \mathrm{~mm}$. Fig. 22: N. piraeeba. Confocal microscope. Scolex. Original. Bar $=0.250 \mathrm{~mm}$. Fig. 23: N. piraeeba. SEM. Sucker with spines. Original. Bar $=0.050 \mathrm{~mm}$. Fig. 24: N. admonticellia. SEM. Scolex, semi-apical view. Suckers located in funnel-shaped portion of scolex. Original. Bar $=0.100 \mathrm{~mm}$. 
1975), Rudolphiella piranabu (Woodland, 1934), Choanoscolex abscisus (Riggenbach, 1895), Jauella glandicephalus Rego \& Pavanelli, 1985 and Paramonticellia itaipuensis Pavanelli \& Rego, 1991. The "collar-like" is the most important type and the more developed metascolex, but in each genus the "collar" has different shapes.
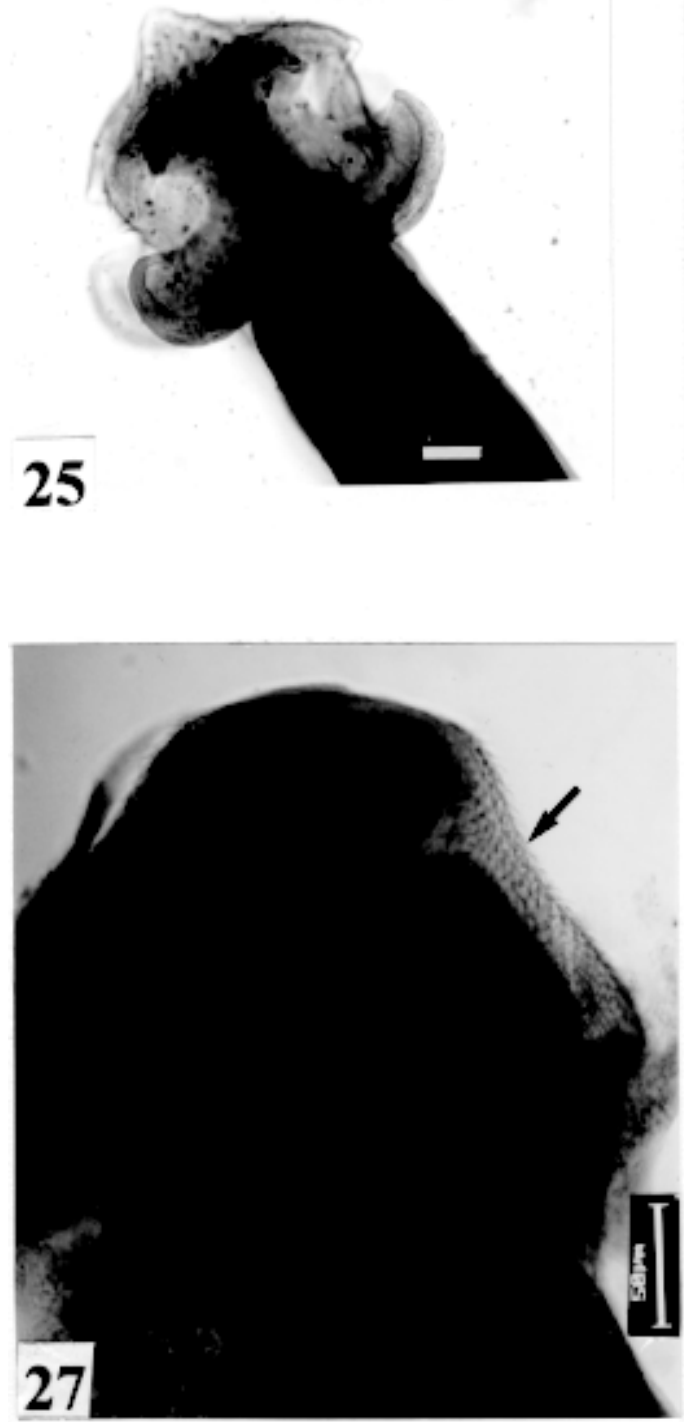

Note that the metascolex can exhibit variations even in the same species, on depending on the conditions of fixation of scolex/metascolex; contracted, the aspect is somewhat different from the expanded ones.

- Spatulifer rugosa. There are developed folds of metascolex, posteriorly to the scolex, some irregu-
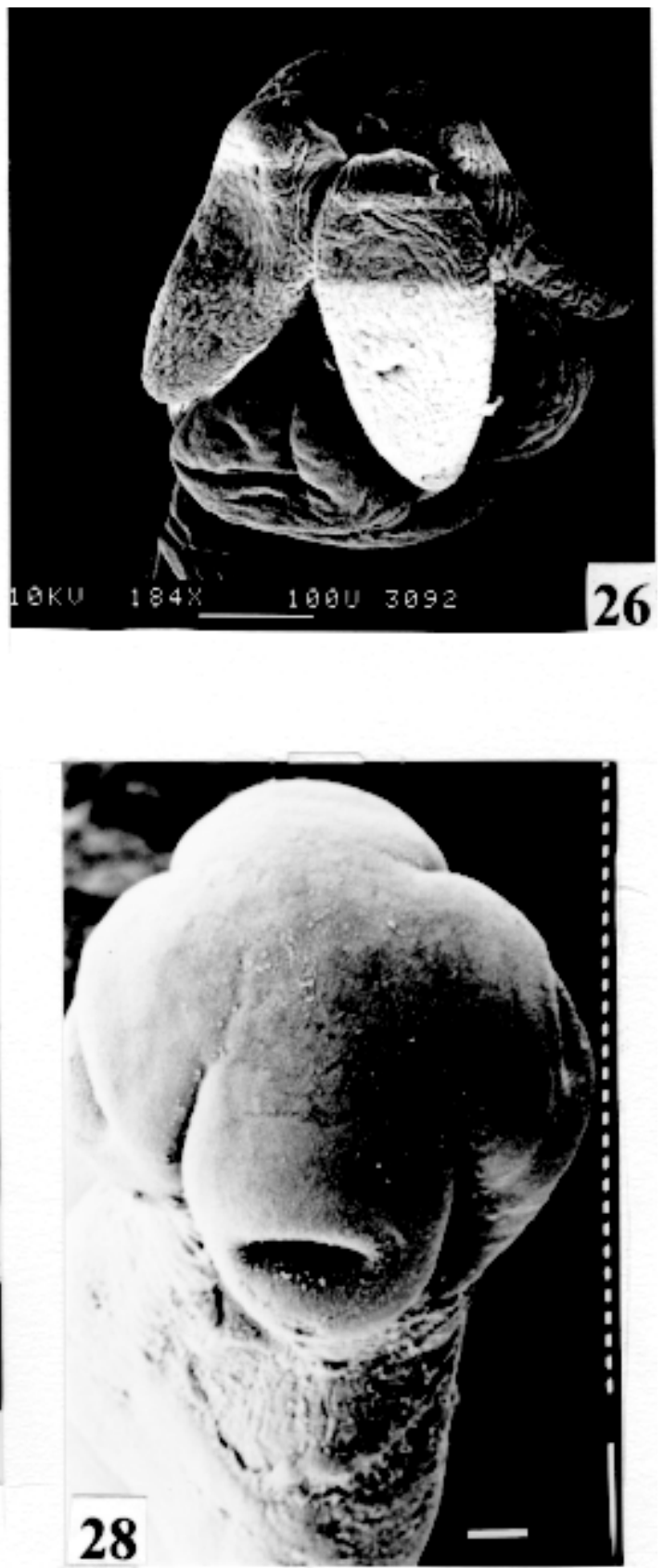

Fig. 25: Proteocephalus piramutab. Light microscope. Scolex. Original. Bar $=0.050 \mathrm{~mm}$. Fig. 26: Nomimoscolex sudobim. SEM. Scolex. Suckers elongated. Original. Bar $=0.100 \mathrm{~mm}$. Fig. 27: Monticellia spinulifera . Confocal microscope. Scolex somewhat wrinkled, contracted. Suckers with spines (arrow). Original. Bar $=0.050 \mathrm{~mm}$. Fig. 28: Travassiella avitellina. SEM. Scolex small, suckers salient. Original. Bar $=0.050 \mathrm{~mm}$. 
lar and other oriented longitudinally; suckers large; generally the uniloculate suckers are not enveloped by these folds, specially in non contracted specimens (Figs 36, 37).

- Peltidocotyle rugosa. Developed folds of metascolex, encircling the scolex; folds mostly oriented longitudinally, but some are irregularly transverse. Small biloculate suckers can be seen in the expanded scolex/metascolex (Fig. 9).

- Othinoscolex lenha [Syn.: O. myzofer Woodland, 1933; Woodlandiella myzofera (Freze, 1965)].
Woodland (1933 a,b) described two Othinoscoles species from the same species of host; he differentiated $O$. lenha from $O$. myzofer by the abscence of suckers, but recent examination of the types, showed the presence of suckers in the $O$. lenha (Chambrier, pers. comm.); consequently it is not necessary to maintain the species $O$. myzofer and the genus Woodlandiella proposed by Freze (1965), who based this genera due to the presence of suckers in the species O. myzofer. Developed folds of metascolex encircles the scolex;
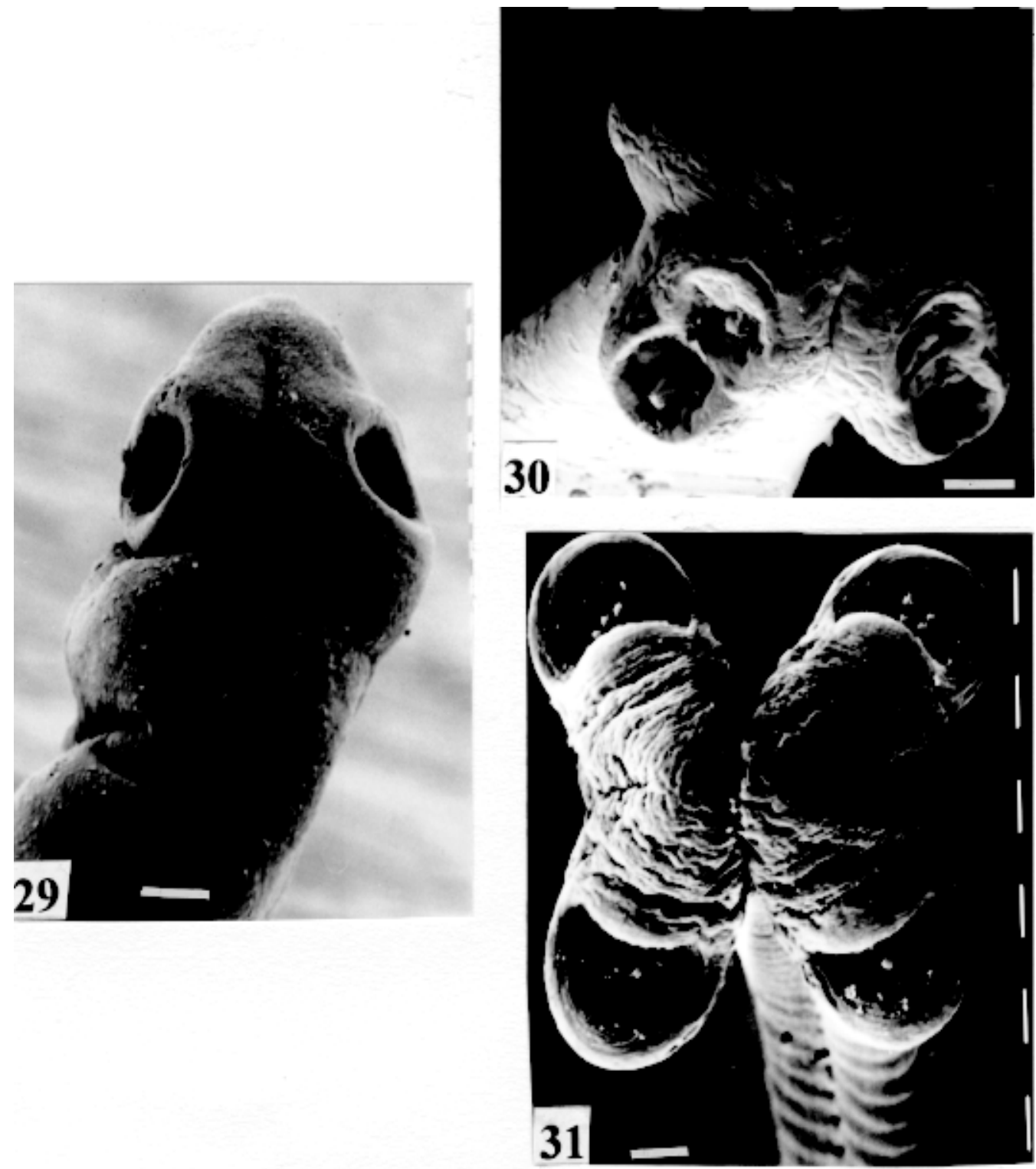

Fig. 29: Cangatiella arandasi. SEM. Scolex small, not well delimited from neck. Original. Bar = 0.100 mm. Fig. 30: Robertiella paranaensis. SEM. Scolex with biloculate suckers disposed antero-lateraly. Original. Bar $=0.100 \mathrm{~mm}$. Fig. 31: Nomimoscolex pirarara. SEM. Scolex pleomorphic, with a wrinkled apex. Suckers oriented anteriorly. Original. Bar $=0.100 \mathrm{~mm}$. 
there is an apical region; the biloculate suckers generally are not visible, or visible only when the scolex is expanded (Fig. 10).

- Rudolphiella rugata. There are developed folds of metascolex encircling the massive scolex; folds not oriented longitudinally, but irregularly; uniloculate suckers of medium size, difficult to seen in non expanded scolex (Fig. 38).

- Rudolphiella piranabu. Larger folds encircling the massive scolex; folds more delicate over the entire escolex, suckers uniloculate, oriented antero- laterally (Fig. 39).

- Amphoteromorphus peniculus. Larger metascolex, with numerous folds, wrinkles and digitiform processes; sometimes with a cauliflower aspect; scolex comparatively small, with biloculate suckers, emerging from the center of metascolex (Fig. 40).

- Amphoteromorphus piraeeba. Large metascolex, similar to A. peniculus; important folds encircling the scolex; suckers biloculate, usually covered by folds and digitiform processes of metascolex (Fig. 34).
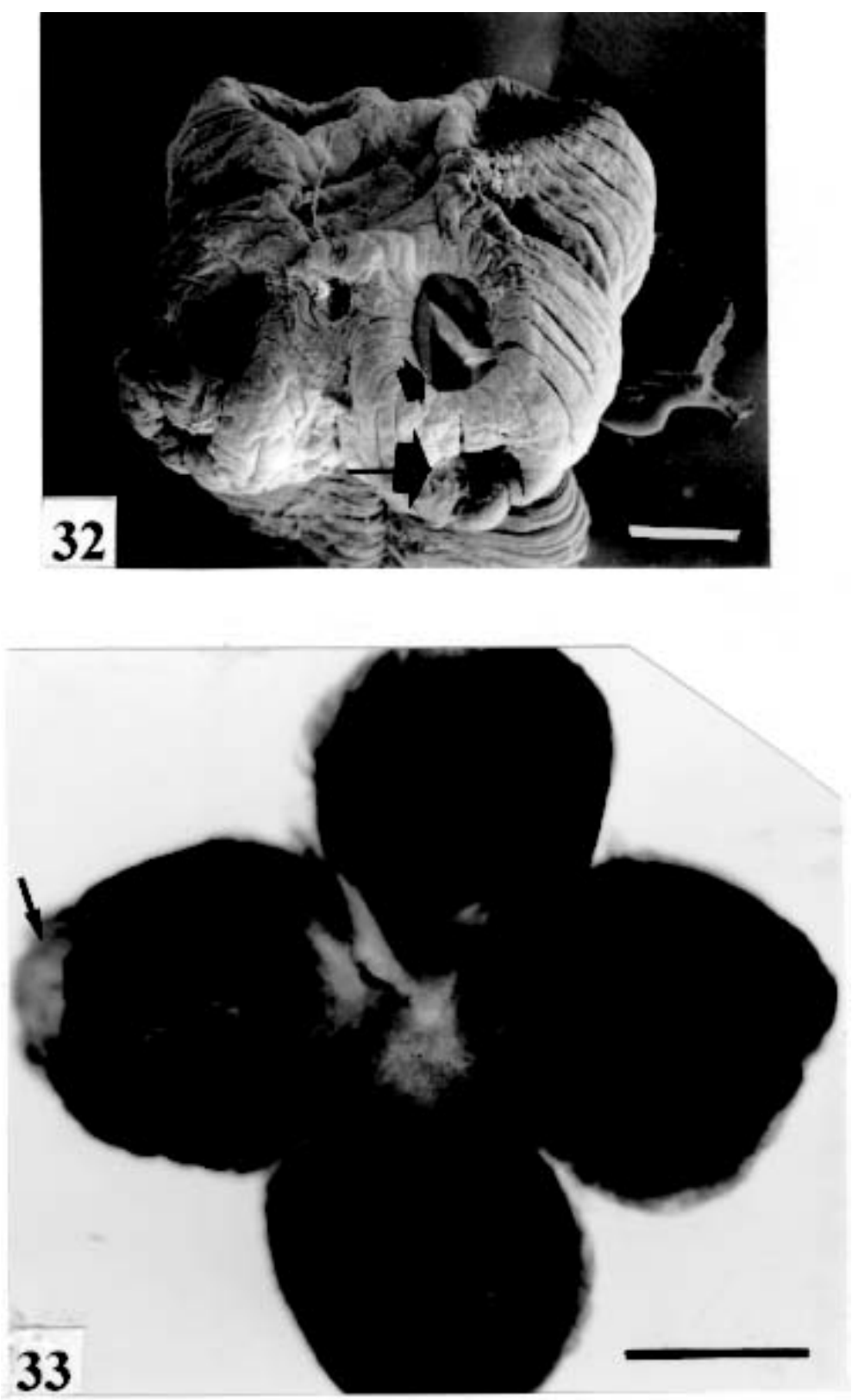

Fig. 32: Zygobothrium megacephalum. SEM. Scolex and suckers very wrinkled. Two appertures on each sucker (arrows). Original. Bar $=1 \mathrm{~mm}$. Fig. 33: confocal microscope. Apical view of scolex. Note the two appertures of sucker (arrows). Original. Bar $=1 \mathrm{~mm}$. 
- Megathylacus brooksi. Scolex massive, globular, pleomorphic, that is to say, the form vary depending on the metascolex/scolex is contracted or expanded; it is not conspicuous when expanded; with wrinkles, no folds, on entire scolex not folds; when contracted, we observe a sort of "collar" encircling the scolex; in this case the suckers not vis-
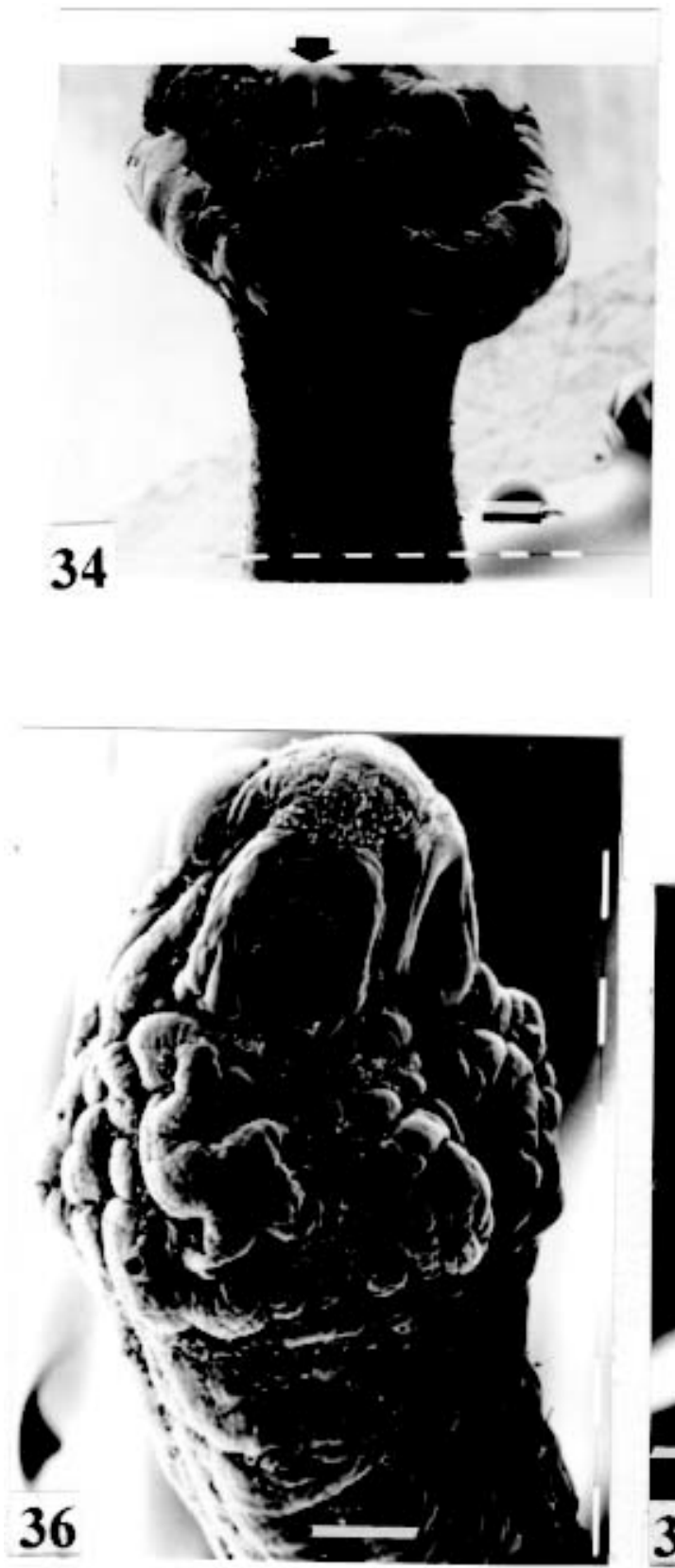

ible, appearing as holes (Figs 17, 41); they are internal, sac-like, and in sections they appear very strong, with well developed sphincter (Fig. 16).

- Jauella glandicephalus. Metascolex coneshaped, very retractile; has the particularity to across the intestinal wall attaining the peritoneum of host; the metascolex acting as a stopper to re-
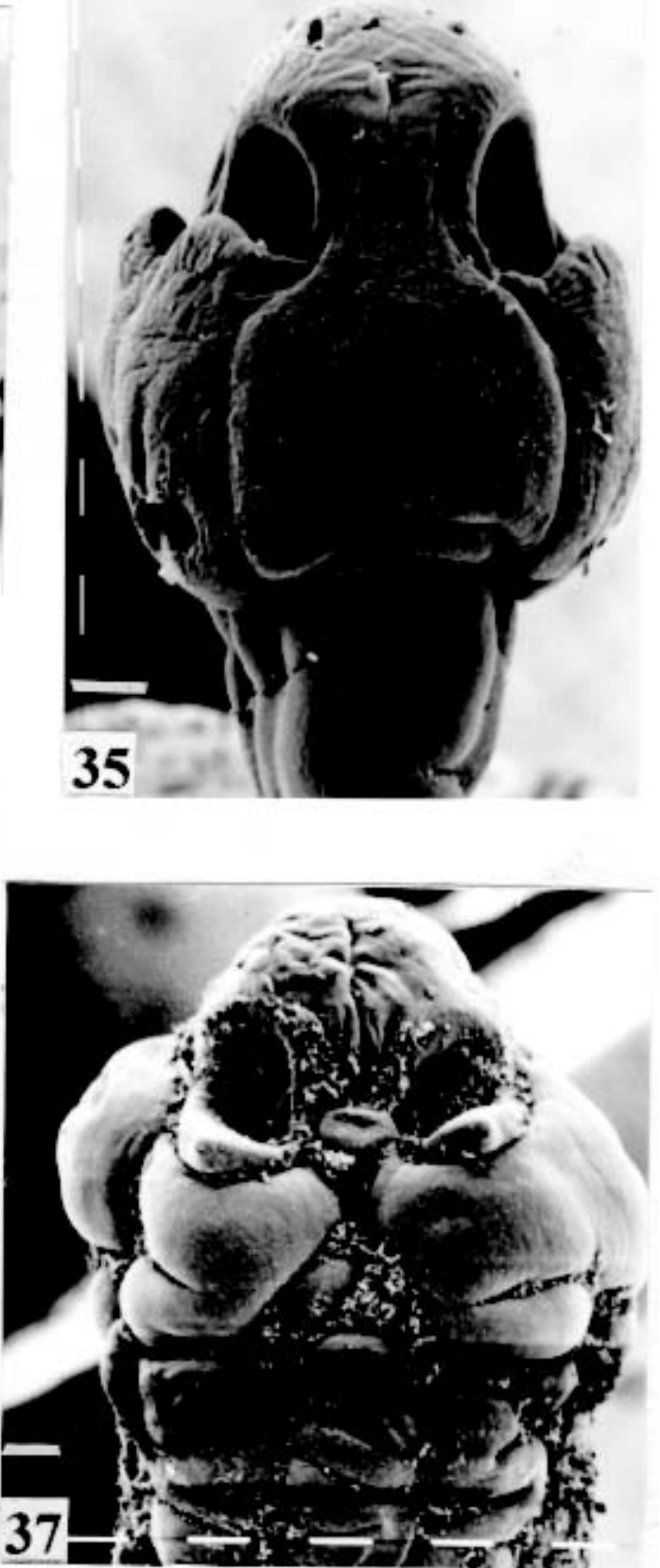

Fig. 34: Amphoteromorphus piraeeba. SEM. Metascolex "collar-shaped"; suckers biloculate partially seen (arrow). Original. Bar $=0.200 \mathrm{~mm}$. Fig. 35: Choanoscolex abscisus. SEM. Scolex; the folds of metascolex covers only the base of suckers. Original. Bar $=0.050 \mathrm{~mm}$. Fig. 36: Spatulifer rugosa. SEM. Scolex well delimited from the folds of metascolex. Suckers uniloculate. Original. Bar $=0.200 \mathrm{~mm}$. Fig. 37: S. rugosa. SEM. Scolex/metascolex somewhat contracted; folds seems different from the anterior specimen. Original. Bar $=0.100 \mathrm{~mm}$. 
tain the parasite in place. Scolex small, apical, quadrangular, suckers uniloculate, orientated anterolaterally (Figs 42, 43). Presence of apical glandular region only seen by sections of scolex.

- Choanoscolex abscisus. Scolex conical; metascolex well delimited from neck, and with well developed folds, but limited to the base of scolex; resulting that only part of suckers are enveloped by the metascolex. Suckers large, uniloculate, oriented laterally (Fig. 35).

- Paramonticellia itaipuensis. There is not a defined metascolex; folds and wrinkles cover entirely the scolex; scolex round; suckers uniloculate, appearing as holes, they are internal, sac-like (Fig. 18).
Neck - Is the non-segmented region situated after the scolex/metascolex; it is inconspicuous in some species (Fig. 5), elongated in others (Fig. 6).

\section{DISCUSSION}

The taxonomy of Proteocephalidea was established mostly based on the papers of Woodland (1925,1933-1935), Wardle and McLeod (1952), Yamaguti (1959), Freze (1965), Brooks (1978), Brooks and Rasmussen (1984) Schmidt (1986) and Rego (1994). The scheme of classification has its foundation in the disposition of vitelline follicles and gonads in relation to the internal longitudinal muscles (medullar in Proteocephalidae; cortical/ medullar in Monticelliidae). Rego (1994) criticised
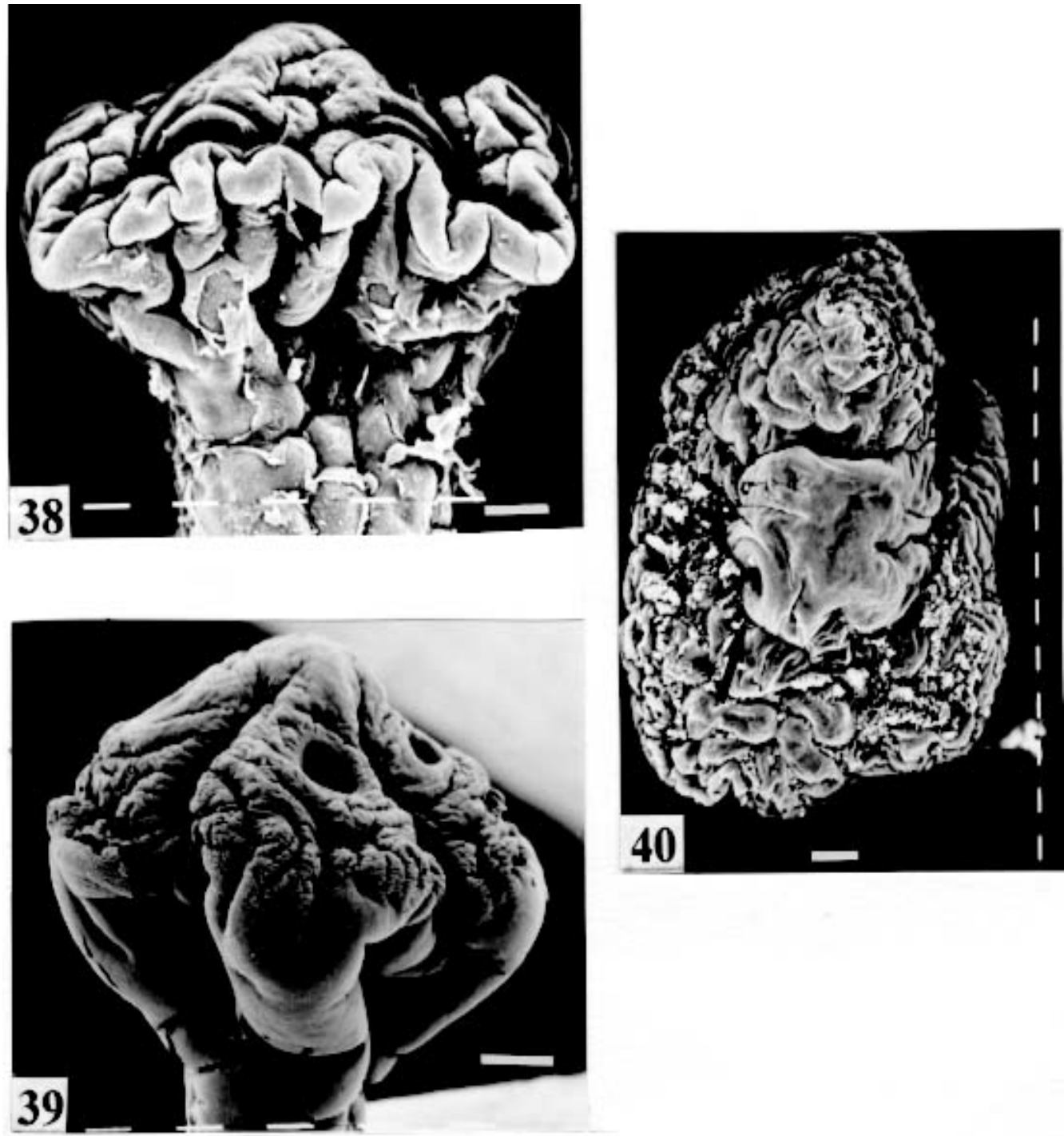

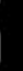

Fig. 38: Rudolphiella rugata. SEM. Scolex; suckers uniloculate, partially seen in contracted specimen (arrow). Original. Bar = $0.100 \mathrm{~mm}$. Fig. 39: Rudolphiella piranabu. SEM. Scolex extended. Suckers relatively small are easily observed. Original. Bar $=$ $0.200 \mathrm{~mm}$. Fig. 40: Amphoteromophus peniculus. SEM. Scolex view from above; there is an apex and the suckers (arrow) are partially hidden by folds and digitiform processes of metascolex. Original. Bar $=0.200 \mathrm{~mm}$. 
this scheme of classification, suggesting that the recent discovery of South American species with intermediate characteristics, could invalidate the Monticelliidae and its subfamilies, which were established on the base of the disposition cortical-
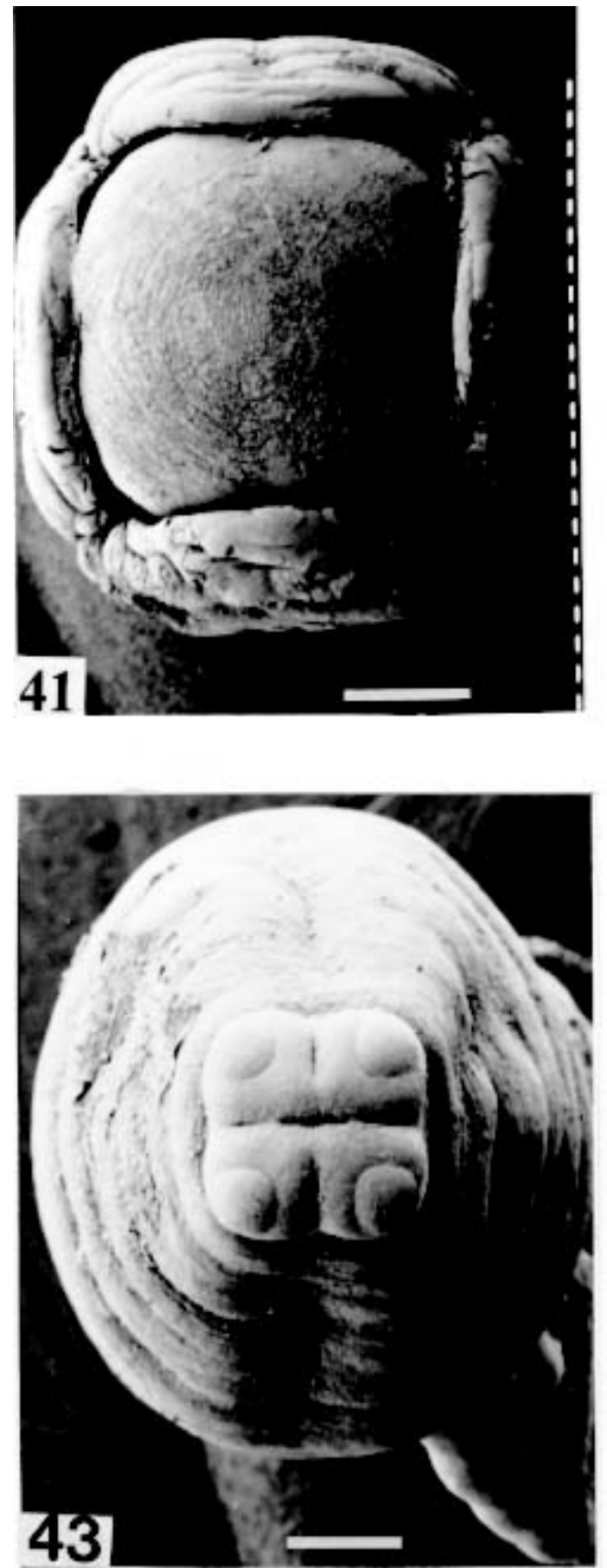

medullary of the reproductive organs. He recommended to pay more attention to the scolex characteristics to define family and subfamily level taxa. The morphological aspects of the scolex actually were not emphasized in the species descrip-

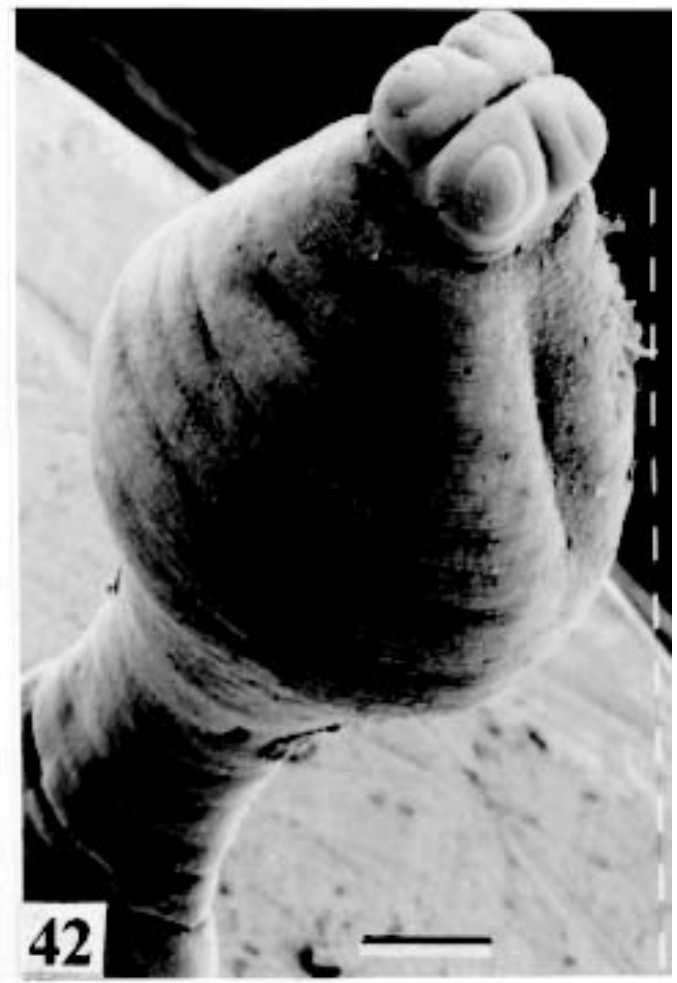

Fig. 41: Megathylacus brooksi. SEM. Scolex somewhat contracted; the suckers are not seen, hidden by the "collar-like" folds of metascolex. Original. Bar $=0.500 \mathrm{~mm}$. Fig. 42: Jauella glandicephalus. SEM. scolex and metascolex expanded; transverse wrinkles; suckers in apical part of scolex (arrow). Original. Bar $=0.200 \mathrm{~mm}$. Fig. 43: J. glandicephalus. SEM. Scolex quadrangular, view from above. Original. Bar $=0.200 \mathrm{~mm}$. 
tion and generical classification. Rego (1995) proposed a radical solution, which was to eliminate the taxa Monticelliidae, and to accept only one family, Proteocephalidae, for the South American species, with two subfamilies, Corallobothriinae and Proteocephalinae, for the species with or without a metascolex. Rego et al. (1998) published a cladistic analyses of proteocephalid subfamilies; the Monticelliid sufamilies were provisionally maintained, depending of further phylogenetic analyses of the South American genera.

Hoberg et al. (1997) evaluated the phylogeny of the Eucestoda. The results of the analyses showed the Proteocephalidea as the sister-group of the Nippotaeniidea + Tetrabothriidea and Cyclophyllidea; additionally the Lecanicephalidea are basal to the Proteocephalidea. Mariaux (1998) examined the relationships among orders of Eucestoda by utilizing sequences of $18 \mathrm{rDNA}$. These results indicated a putative sister-group relationship beteween the Proteocephalidea and Diphyllidea, but other relatioships depicted among the tetrafossate groups were largely congruent to the morphological analysis. These latter results, with the placement of the Diphyllidea, are surprising, as neither the anatomy nor the life history of either group suggested a link. However, in my opinion, the most acceptable phylogeny developed by Freeman (1973), based on ontogeny of the cestodes, stressed a close relationship between the Tetraphyllidea (along with the Lecanicephalidea and Diphyllidea) and the Proteocephalidea. Additionally, Freeman considered the Proteocephalidea to be diphyletic, and to contain two independent lineages of the Cyclophyllidea, which would make the former order paraphyletic. As such this would invalidate both the Proteocephalidea as currently defined. In my opinion it will be necessary to complete more studies to elucidate the apparently problematic relatiosnhips among the orders of the Eucestoda.

Recently, Scholz et al. (1998), published an study by SEM and light microscopy, of Proteocephalus species from Palearctic region; he stated that "the scolex represents a relatively stable structure, possessing species-specific characters in some taxa". "The present observations also stressed the necessity of providing comparable data on the scolex morphology of other Proteocephalus species...". In my opinion the species of Proteocephalus have very similar scolex, that also compels a careful study of the reproductive system to differentiate morphologically the species. This is not the case of the Neoptropical species, which fauna has many monotypic genera, and very different morphologically types of scolex/ metascolex.
The purpose of this study is to provide data in order to characterize the proteocephalid scolex and metascolex of the species described from South American freshwater fishes. This is justified because most of the known species were described with few details of the morphology of the metascolex, probably due to the difficulties to sketch the complicate morphology of these structures. Recently, with the aid of the scanning electron microscopy, the scolices and metascolices are being better scrutinized and the species, better described.

In the author' opinion, morphological characteristic of metascolex and scolex, that include frontal glands, apical sucker, appendices of suckers and spines or microtriches, could provide more precise data in order to separate genera and subfamilies rank in the group or Proteocephalidea, naturally, allied to the description of disposition of gonads and vitellaria in relation to internal longitudinal musculature. Consequently, it is crucial to characterize morphologically each type of metascolex and the other characteristics of scolex.

\section{ACKNOWLEDGMENTS}

To CJ Weltkamp and Dr JC Chubb (School of Biological Sciences, University of Liverpool) from SEM of most scolices illustrating this work. To Dr GC Pavanelli (Nupelia, Paraná) for providing copies of SEM photographs of proteocephalid species. To Dr Alain de Chambrier (Museum of Natural History, Geneva) for providing unpublished data, and also to Bruno Silva Vale (Dept. of Pathology, Oswaldo Cruz Institute) for some scolices photographs on Zeiss confocal microscope.

\section{REFERENCES}

Brooks DR 1978. Evolutionary history of the cestode order Proteocephalidea. Systematic Zool 27: 312-323.

Brooks DR, Rasmussen G 1984. Proteocephalidean cestodes from Venezuelan siluriform fishes with a revised classification of the Monticelliidae. Proc Biol Soc Washington 97: 748-760.

Chambrier A de, Paulino RP 1997. Proteocephalus joanae sp. n. (Eucestoda : Proteocephalidea) parasite de Xenodon neuwiedi (Serpentes: Colubridae) from South America. Folia Parasitol 44: 289-296.

Freeman RS 1973. Ontogeny of Cestodes and its bearing on their phylogeny and systematics. Advances in Parasitol 11: 481-557.

Freze VI 1965. Essentials of Cestodology, Volume 5, Proteocephalata. In Fish, Amphibians and Reptilies, English translation 1969, Jerusalem: Israel Program of Scientific Translations, 597 pp.

Hoberg EP, Mariaux J, Justine JL, Brooks DR, Weekes PJ 1997. Phylogeny of the Orders of the Eucestoda (Cercomeromorphae) based on comparative morphology: Historical perspectives and a new working hipothesis. J Parasitol 83: 1128-1147.

Mariaux J 1998. A molecular phylogeny of the Eucestoda. J. Parasitol 84: 114-123. 
Rego AA 1994. Proteocephalidea. In Keys to the Cestode Parasites of Vertebrates, St Albans, CAB International, $751 \mathrm{pp}$.

Rego AA 1995. A new classification of the cestode Order Proteocephalidea Mola. Rev Bras Zool 12: 791-814.

Rego AA, Chambrier A de, Hanzelová V, Hoberg E, Schólz T, Weekes P, Zehnder M 1998. Preliminary phylogenetic analysis of subfamilies of the Proteocephalidea (Eucestoda). Syst Parasitol 40: 1-19.

Rego AA Chubb JC, Pavanelli GC in press. Cestodes in South American freshwater teleost fishes: keys to genera and brief description of species. Rev Bras Zool

Scholz T, Drábek R, Hanzelová V 1998. Scolex morphology of Proteocephalus tapeworms (Cestoda: Proteocephalidae), parasites of freshwater fish in the Palearctic Region. Folia Parasitol 45: 27-43.

Schmidt GD 1986. CRC Handbook of Tapeworm Identification, CRC Press Inc., Boca Raton, Florida, 675 pp.

Wardle RA, McLeod JA 1952. The Zoology of Tapeworms, The University of Minnesota Press, Minneapolis, $780 \mathrm{pp}$.

Woodland WNF 1925. On some remarkable new Monticellia-like and other cestodes from Sudanese siluroids. Quarterly J Microsc Sc 69: 703-729.

Woodland WNF 1933a. On the anatomy of some fish cestodes described by Diesing from the Amazon. Quarterly J Microsc Sc 76: 175-208.
Woodland WNF 1933b. On two new cestodes from the Amazon siluroid fish Brachyplatystoma vaillanti Cuv. and Val. Parasitology 25: 485-490.

Woodland WNF 1933c. On a new subfamily of proteocephalid cestodes - the Othinoscolecinae from the Amazon siluroid fish Platystomatichthys sturio (Kner). Parasitology 25: 491-500.

Woodland WNF 1934a. On the Amphilaphorchidinae, a new subfamily of proteocephalid cestodes, and Myzophorus admonticellia, gen. et sp.n., parasitic in Pirinampus spp. from the Amazon. Parasitology 26: 141-149.

Woodland WNF 1934b. On some remarkable new cestodes from the Amazon siluroid fish, Brachyplatystoma filamentosum (Lichtenstein). Parasitology 26: 268-277.

Woodland WNF 1934c. On six new cestodes from Amazon fishes. Proc Zool Soc London 104: 33-44.

Woodland WNF 1935a. Additional cestodes from the Amazon siluroids pirarará, dorad and sudobim. Proc Zool Soc London 104: 851-862.

Woodland WNF 1935b. Some more remarkable cestodes from Amazon siluroid fish. Parasitology 27: 207-225.

Woodland WNF 1935c. Some new proteocephalids and a ptychobothriid (Cestoda) from the Amazon. Proc Zool Soc London 105: 619-623.

Yamaguti S 1959. Systema Helminthum, Vol II, The Cestodes of Vertebrates, Interscience, New York \& London, $860 \mathrm{pp}$. 